\title{
SYNTHESIS AND ANTIBACTERIAL ACTIVITY OF ACETOXYBENZOYL THIOUREAS WITH ARYL AND AMINO ACID SIDE CHAINS
}

\author{
Zainab Ngaini, ${ }^{1}$ Maya Asyikin Mohd Arif, ${ }^{1}$ Hasnain Hussain, ${ }^{2}$ \\ Er Su Mei, ${ }^{1}$ Donna Tang, ${ }^{1}$ and Dyg Halimatulzahrah \\ Abang Kamaluddin ${ }^{1}$ \\ ${ }^{I}$ Department of Chemistry, \\ ${ }^{2}$ Department of Molecular Biology, Faculty of Resource Science and Technology, \\ University Malaysia Sarawak, Kota Samarahan, Sarawak, Malaysia
}

\section{GRAPHICAL ABSTRACT}

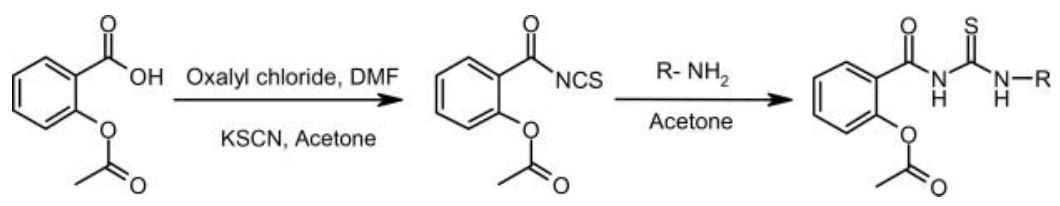

Abstract A series of acetoxybenzoylthioureas derivatives with aryl and amino acid ester side chains were prepared by reaction of acetoxybenzoyl isothiocyanate, an acyloxy benzyl esterbased derivative of aspirin, with aryl amines or amino-functionalized amino acids with overall yields of 46-73\%. The products that display a thiourea segment as a linker showed improved antibacterial properties in comparison with aspirin. The structures of the synthesized compounds were characterized by infra red spectroscopy, ${ }^{13} \mathrm{C}$ nuclear magnetic resonance (NMR), and ${ }^{I} H$ NMR spectroscopy. The compounds were screened for their antibacterial activity by using gram-negative bacteria (E. coli ATCC 8739). [2-(phenylcarbamothioylcarbamoyl)phenyl] acetate showed the highest antibacterial activity against E. coli compared with other synthesized compounds.

Supplemental materials are available for this article. Go to the publisher's online edition of Phosphorus, Sulfur, and Silicon and the Related Elements to view the free supplemental file.

Keywords Thiourea; aspirin; amino acid; antibacterial activity

\section{INTRODUCTION}

Aspirin has been widely used as an analgesic and anti-inflammatory drug. It also plays an important role in the prevention of cardiovascular diseases and cancer. Modification

Received 23 November 2010; accepted 30 January 2011.

The authors wish to thank the University Malaysia Sarawak and the Ministry of Science, Technology, and Innovation (MOSTI) for the financial support through research grants 01(S27)684/2008(19) and FRGS/01(14)/743/2010(29), respectively. The authors would also like to thank Associate Professor Dr. Ling Teck Yee for providing technical help for this manuscript.

Address correspondence to Dr. Zainab Ngaini, Associate Professor, Department of Chemistry, Faculty of Resource Science and Technology, University Malaysia Sarawak, 94300 Kota Samarahan, Sarawak, Malaysia. E-mail: nzainab@frst.unimas.my 